ISSN 1991- 8690

Website: http://jsci.utq.edu.iq

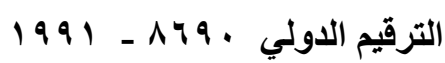

Email: utjsci@utq.edu.iq

\title{
Seroprevalence of Cytomegolovirus Infection among Aborted Women in Thi-Qar \\ Governorate
}

\author{
Ahmad H. Al-Khafaji \\ M .Sc. (Med. Microb.)
}

Kawakib I. Al-Zubaidi

M.Sc. (Med. Microb.)

\begin{abstract}
$\underline{\text { Abstract }}$
Venous blood had been collected from sexity women with habitual abortion from Thi-Qar Governorate cities to study and evaluate the prevalence of Cytomegalovirus infection and from twenty healthy looking women as control.

The test performed using ELISA method to detect the IgM and IgG antibodies in patients and control sample by commercial kit.

The result showed that 60 of 60 women (100\%) had antibodies against CMV, 9 (15\%) with IgM antibodies, 21 (35\%) with $\mathrm{IgG}$ antibodies and 30 (50\%) with both $\mathrm{IgM}$ and $\mathrm{IgG}$ antibodies. Other women (controls) they were negative for CMV infection.
\end{abstract}

\section{$\underline{\text { Introduction }}$}

Cytomegalovirus (from the Greek cyto-, "cell", and -megalo-, "large") is a viral genus of the Herpesviruses group: in humans it is commonly known as HCMV or Human Herpesvirus 5 (HHV5). HCMV infections are frequently associated with salivary glands, though they may be found throughout the body. HCMV infection can also be life threatening for patients who are immunocompromised (e.g. patients with HIV, organ transplant recipients, or neonates). Other CMV viruses are found in several mammal species, but species isolated from animals differ from HCMV in terms of genomic structure, and have not been reported to cause human disease (Ryan \& Ray, 2004). HCMV is found throughout all geographic locations and socioeconomic groups, and infects between $50 \%$ and $80 \%$ of adults in the United States as indicated by the presence of antibodies in much of the general population. 
HCMV is also the virus most frequently transmitted to a developing fetus. HCMV infection is more widespread in developing countries and in communities with lower socioeconomic status and represents the most significant viral cause of birth defects in industrialized countries (Staras et al., 2006).

Cytomegalovirus (CMV) can cross the placenta and cause both fetal and placental infections. Most congenital infections are asymptomatic; only $10 \%$ of fetuses infected in utero will develop clinical signs of CMV infection. Studies have shown that infants congenitally infected with CMV as a result of primary infection of their mothers are more likely to have overt sequelae than those infected from reactivated infections of the mothers (Stango S. 1982 \& Schopfer et al., 1978). Transmission of CMV infection to the fetus has been identified in all trimesters of pregnancy. Abortion can result from ascending $\mathrm{CMV}$ endometritis and the virus has been isolated from post-abortion uterine discharge (Dehner \& Askin, 1975). The usual manifestations of overt CMV infection at birth are hepatosplenomegaly,jaundice, thrombocy topenia and various congenital malformations, especially those involving the central nervous system (Hanshaw, 1971. \& Al- Ali et al., 1999).

Transmission of HCMV occurs from person to person through bodily fluids. Infection requires close, intimate contact with a person excreting the virus in their saliva, urine, or other bodily fluids. CMV can be sexually transmitted and can also be transmitted via breast milk, transplanted organs, and rarely from blood transfusions (Ryan \& Ray, 2004).
Most infections with CMV are not diagnosed because the virus usually produces few, if any, symptoms and tends to reactivate intermittently without symptoms. However, persons who have been infected with CMV develop antibodies to the virus, and these antibodies persist in the body for the lifetime of that individual (Bennkoy et al., 2004). A number of laboratory tests that detect these antibodies to CMV have been developed to determine if infection has occurred and are widely available from commercial laboratories. In addition, the virus can be cultured from specimens obtained from urine, throat swabs, bronchial lavages and tissue samples to detect active infection. Both qualitative and quantitative polymerase chain reaction (PCR) testing for $\mathrm{CMV}$ are available as well, allowing physicians to monitor the viral load of CMV-infected patients. The enzymelinked immunosorbent assay (or ELISA) is the most commonly available serologic test for measuring antibody to CMV. The result can be used to determine if acute infection, prior infection, or passively acquired maternal antibody in an infant is present. Other tests include various fluorescence assays, indirect hemagglutination, (PCR) and latex agglutination (Adler, 2005).

Our study was designed to follow up the number of women with habitual abortion have a serological evidence of cytomegalovirus infection.

\section{Subjects and Methods}

This study was carried out on eighty women attending the outpatient gynecology clinics in different cities in Thi - Qar Governorate between March 2007 and December 2007. The study 
group consists of sixty women with habitual abortion and twenty women looking healthy with no history of abortion as control. Their ages ranged between $25-45$ years. Clinical examination and laboratory investigation were carried out for those with habitual abortion in order to exclude other causes of fetal wastage such as malformation of genital tract, diabetes mellitus, renal disease, toxoplasmosis or Rhesus incompatibility.

Venous blood was collected from the patients and controls, then the serum was separated by centrifugation of blood samples at $3000 \mathrm{rpm}$ for 5 minutes, then the sera stored at $4{ }^{\circ} \mathrm{C}$ until use.

Samples were tested for CMV IgM and IgG by ELISA kits commercially available from Biocheck Inc. USA. Samples were tested strictly according to the manufacturer's instructions. The results read by a microwell reader compared in a parallel manner with calibrator and controls.

Interpretation: $\mathrm{CMV} \operatorname{IgM}$ and $\mathrm{IgG}$ have the same index, where less than 0.90 taken as negative, between 0.90 and
1.00 is equivocal, and 1.00 or greater is positive for IgM antibody indicates the current or recent infection, while for $\mathrm{IgG}$ antibody indicates past or chronic infection and with both $\operatorname{IgM}$ and $\operatorname{IgG}$ indicate as recurrent infection.

\section{The Results}

Sixty samples of women's serum had been tested for specific $\operatorname{IgG}$ and $\operatorname{IgM}$ antibodies to confirm the presence of CMV infection in those women by using ELISA kit (Biocheck diagnostics Inc. USA).

The results showed that 60 of 60 women $(100 \%)$ (Table 1) have antibodies against CMV, 9 (15\%) (Table 2) of which have IgM antibody and no IgG, 21 (35\%) (Table 3) have IgG and no IgM and $30(50 \%)$ (Table 4) have both $\mathrm{IgG}$ and $\mathrm{IgM}$.

On the other hand, samples from 20 healthy looking women were collected as controls and tested for IgG and IgM specific antibodies for CMV infection by using ELISA kit. The results indicated that 20 women were negative to IgG and IgM of CMV.

Table 1: Prevalence of Cytomegalovirus antibody using ELISA in women with habitual abortion compared with healthy controls.

\begin{tabular}{|c|c|c|c|}
\hline Types of Cases & ELISA Positive & ELISA Negative & Total \\
\hline \hline Abortion & $60(100 \%)$ & $0(0 \%)$ & $60(100 \%)$ \\
\hline \hline Controls (No abortion) & $0(0 \%)$ & $20(100 \%)$ & $20(100 \%)$ \\
\hline \hline Total & $60(100 \%)$ & $20(100 \%)$ & $80(100 \%)$ \\
\hline
\end{tabular}


Table 2: Prevalence of CMV IgM antibody using ELISA in seropositive women with habitual abortion compared with healthy controls.

\begin{tabular}{|c||c||c||c|}
\hline Types of cases & IgM positive & IgM Negative & Total \\
\hline \hline Abortion & $9(15 \%)$ & $51(85 \%)$ & $60(100 \%)$ \\
\hline \hline Controls (no abortion) & $0(0 \%)$ & $20(100 \%)$ & $20(100 \%)$ \\
\hline \hline Total & $9(11.25 \%)$ & $71(88.75 \%)$ & $80(100 \%)$ \\
\hline
\end{tabular}

Table3: Prevalence of CMV IgG antibody using ELISA in seropositive women with habitual abortion compared with healthy controls

\begin{tabular}{|c|c|c||c|}
\hline Types of Cases & IgG Positive & IgG Negative & Total \\
\hline \hline Abortion & $21(35 \%)$ & $39(65 \%)$ & $60(100 \%)$ \\
\hline \hline Controls (no abortion) & $0(0 \%)$ & $20(100 \%)$ & $20(100 \%)$ \\
\hline \hline Total & $21(26.25 \%)$ & $59(73.75 \%)$ & $80(100 \%)$ \\
\hline
\end{tabular}

Table4: Prevalence of CMV IgM and IgG antibodies using ELISA in seropositive women with habitual abortion compared with healthy controls

\begin{tabular}{|c|c|c||c|}
\hline Types of cases & $\begin{array}{c}\text { IgM \& IgG } \\
\text { Positive }\end{array}$ & I gM \& IgG Negative & Total \\
\hline \hline Abortion & $30(50 \%)$ & $30(50 \%)$ & $60(100 \%)$ \\
\hline \hline Controls (no abortion) & $0(0 \%)$ & $20(100 \%)$ & $20(100 \%)$ \\
\hline \hline Total & $30(37.5 \%)$ & $50(62.5 \%)$ & $80(100 \%)$ \\
\hline
\end{tabular}

\section{$\underline{\text { Discussion }}$}

Congenital CMV infection can be the result of either exogenous or endogenous maternal infection. While exogenous infection can be primary or non-primary as it can occur in both seronegative and seropositive women. Endogenous infection is the result of reactivation of latent virus. Primary infection in the mother has a much greater clinical impact on the fetus than recurrent infection or exogenous reinfection (Landini \& Lazzarotto, 1999). Cytomegalovirus infection during pregnancy is far more complex than other infections, due to the ability of the virus to be frequently reactivated during the child bearing age and be transmitted 
to the fetus inspite of maternal immunity (Stagno et al., 1977).

In India, serological surveys have shown the prevalence of CMV antibodies in adult population to be about 80-90\% (Mukundan et al., 1977. \& Mathur et al., 1981).

In Iraq, studies have revealed that the majority of women of childbearing age are seropositive for CMV and that they contract the infection either through prenatal or postnatal transmission or during early childhood (Ali et al., 1992 \& Abdul-Kareim, 1989). Sexual transmission and blood transfusion are other sources of infection. Primary CMV infection has been found to be more prevalent in pregnant women than in non-pregnant women. This difference may be attributed to the susceptibility of seronegative women, at the onset of pregnancy, to their first CMV infection (Schopfer et al., 1978). CMV infection is endemic in Iraq; the prevalence rates of cytomegalovirus IgM and $\mathrm{IgG}$ antibodies in non-pregnant women have been reported to be $1 \%$ and $84 \%$ respectively, and $2.5 \%$ and $90 \%$ in pregnant women. Our study revealed the same result, where the incidence of CMV infection among aborted women was 100\%, 50\% of infection was by detection of both $\operatorname{IgM}$ and $\mathrm{IgG}$ antibody, and this indicate to reinfection. While the primary infection by detection of the IgM only was $15 \%$, and the past infection by detectionof the IgG only was $35 \%$ (AlAli et al., 1999).

Other studies show the same occusionally the same results, where in Finland the seropositivity of CMV with IgG antibody reach to $70.7 \%$ while reach to $4 \%$ with IgM antibody.(Mustakangas et al., 2000). In the Kingdom of Saudi
Arabia the incidence of CMV infection among pregnant women by detection of IgG antibody using ELISA was $92.1 \%$ (Ghazi et al., 2002).

All these findings indicate that CMV infection is not uncommon in our local population and this high seroprevalence reflect the low hygienic standards and low community education. Also the many ways of viral transmission have the role in spreading the viral infection, in addition to the missing of effective viral treatment play an major role in the transmission of the virus from mother to fetus and cause either abortion or congenital malformations (Lone et al., 2004).

\section{References}

1.Abdul-ariem,EA.1989.Seroepidemiology of cytomegalovirus infection among a healthy population in Baghdad. Journal of community medicine. 2:1927.

\section{Adler,SP.2005.Congenital} cytomegalovirus screening. Pediatr. Infect. Dis. J. 24 (12): 1105-6.

3.Al- Ali, HYM., Yasseen, SA. and Raof, TY. 1999. Follow up of pregnant women with active Cytomegalovirus infection. Esat. Medit. Health. J. 5:949-954.

4.Ali , HYM., Yaseen, SA. And Najem, SN.1992.Prevalence of cytomegalovirus infection in childbearing age women in Mosul. Jordan medical journal. 26:53-8.

5.Bennekov,T., Spector, D. and Langhof $f$, E. 2004. Induction of immunity against human cytomegalovirus. Mt. Sinai J. Med. 71 (2): 86-93. 
6.Dehner, LP. and Askin, FB. 1975. Cytomegalovirus endometritis: report

7.abortion. Obstetrics and gynecology. 45:211-4.

8.Ghazi, HO., Telmesani, AM. and Mahomed, MF. 2002. TORCH agent in pregnant saudi women. Med. Princ. Pract. 11: 180-182.

9.Hanshaw, JB. 1971. Congenital cytomegalovirus infection: a fifteen year perspective. Journal of infectious diseases. 123:555-61.

10. Landini, MP. and Lazzarotto, T. 1999. Prenatal diagnosis of congenital cytomegalovirus infection: light and shed. Herpes 6: 2. 45-49.

11. Lone, R., Fomda , BA., Thokar, M., Wani, T., Kakru, D., Shaheen, R. and Nazir, A. 2004. Seroprevalence of Cytomegalovirus (CMV) in Kashmir Valley: a preliminiry Study. J. K. Practitioner. 11 (4): 261-262.

12. Mathur, A., Jindal, L. and Chaturvedi, VC. 1981. A serological study of cytomegalovirus infection at Lucknow. Indian J Med Res. 73:678681.

13. Mukundan, P., Jadvan, M. and John, TJ.1977. Prevalence of cytomegalovirus antibody in young children in Vellore. Indian J Med Res. 65:589-592.

14. Mustakangas, P., Sarna, S., Ammala, P., Muttilanien, M., Koskela, P. and of a case associated with spontaneous

Koskeinemi, M. 2000. Human Cytomegalovirus seroprevalence in three socioeconomically different urban areas during the first trimester: a population based cohort study. Int. J. Epidem. 29. 587-591.

15. Ryan, KJ. And Ray, CG. (editors) 2004. Sherris Medical Microbiology (4th ed.) McGraw Hill. pp. 556; 566 9.

16. Schopfer, K., Lawber, E. and Krech, U. 1978. Congenital cytomegalovirus infection in newborn infants of mothers infected before pregnancy. Archives of disease in childhood. 53:536-9.

17. Stagno, S., Reynolds, DW., Huang, ES., Thompson, SD., Smith, RJ. and Alford, CA. 1977. Congenital cytomegalovirus infection in an immune population. $\mathrm{N}$ Engl $\mathrm{J}$ Med. 296:1254-1258.

18. Stagno, S. 1982. Congenital cytomegalovirus infection: the relative importance of primary and recurrent maternal infection. New England journal of medicine. 306:9459.

19. Staras, SAS., Dollard, SC. and Radford, KW. 2006. Seroprevalence of cytomegalovirus infection in the United States, 1988-1994. Clin. Infect. Dis. 43: 1143-51. 


\section{الخلاصة}

تم سحب عينات من الدم الوريدي لسنين امر اة يعانين من الاجهاض المفاجئ من المدن المختلفة في محافظة ذي قار لغرض تقييم انتشار الاصابة بفايروس CMV فضلا عن اختيار عشرين امر اة طبيعية لا تشكو من اي نوع من الاجهاض كمجموعة سيطرة. شخصت الاجسام المضادة من نوع M ونوع G باستخدام العدد الطبية المتداولة في الاسو اق باستخدام طريقة اليز ا.

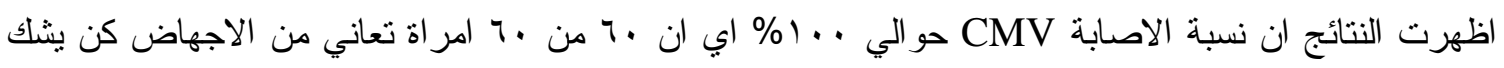
باصابتهن ، حيث اظهرت النتائج ان نسبة الاصابة الحادة اي وجود اجسام مضادة من نوع M بلغت 10\% اي بمقدار و نساء من اصل ، ج امر اة مصابة، اما نسبة الاصابة المزمنة ابي وجود اجسام مضادة من نوع G فقد بلغت هr\% اي حو الى ابامر اة ، بلغت نسبة النساء اللواتي يحملن كلا النوعين من الاجسام المضادة (M و G) . ( M ) اي • ب امر اة اما بقية النساء اللواتي اخترن كمجموعة سبطرة لم تظهر امصالهن وجود اب اجسام مضادة من كلا

$$
\text { النوعين (M و ( G ( ) ( ) }
$$

